\title{
Preface
}

"Systemic Financial Shocks" - henceforth simply "Financial Shocks" have the power to wrench the macroeconomy. They matter for two main reasons. First, even when they come from imbalances external to the financial sector, financial shocks may unnerve society, by impairing asset values and encumbering economic growth. In this case, we may label them as first type - or exogenously determined - financial shocks. Second and more nastily, when their origin comes from finance itself, financial shocks acquire a stronger taint, as they also expose the inner fragility and instability of capitalist systems, building a wide sense of insecurity with possible contagion and domino effects, up to jeopardise the proper functioning of payments systems. Here, we can label them as second type - or endogenously bred - financial shocks. Whatever their origin, it is important to study financial shocks trying to answer the following questions. What causes them? Which channels may exacerbate their impact? What policies may help avoid their occurrence or, when they occur, limit their negative effect on the economy and society?

Answering these questions has become more and more crucial over the latest decades, when financial shocks have become more frequent, their intensity has escalated, their focal point has moved from the periphery to the centre of the world economy, and their nature has been upgraded from first to second type financial shocks. Indeed, from the post-Second-WorldWar up to the 1970s financial shocks had become extremely rare, if not absent. And even thereafter, financial shocks had been main characters only in developing and emerging countries. Up until 2007, one could be led to think that suffering a financial shock was the prerogative of developing and emerging economies, while rich countries - excluding the crises of Japan and the Scandinavian countries in the early 1990s - were rather immune from financial shocks. Hence, it was possible to believe that financial crises were due to more widespread market imperfections and lower quality of institutions outside the developed world. This tenet was, of course, rebuffed when the Global Financial Crisis (GFC) of 2007-09 erupted from America's Wall Street. Moreover, while almost all the previous systemic crises were associated with type one - or exogenously determined - financial shocks, this time around the GFC was clearly 
triggered by a second type - endogenous - financial shock. The GFC, in fact, came about under the initial impetus of the subprime crisis, where a large segment of innovative securities - leveraged on the backing of subprime mortgages, that is, mortgages entrusted to clients with low or no ability to repay - turned sour. Moreover, the GFC was followed by a second wave of instability caused by a broad reassessment of sovereign risks throughout Europe inducing a euro sovereign crisis. Indeed, after the GFC investors discontinued the previously held view that eurozone member countries all shared an analogous and common sovereign risk. As some of the chapters will debate later, the massive market reassessment of sovereign risks, together with some institutional fragilities within the eurozone, caused new intense financial shocks in some member countries. Again, this was a further blow to the naive view that financial crises were reserved to emerging and developing countries.

\section{PLAN OF THE BOOK}

This book consists of four parts: I. Financial Instability after the Global Financial Crisis: Taxonomy and Models; II. Main Channels of Transmission of the Financial Shock; III. The Role of Public Policies; IV. Learning from Past Financial Crises to Prevent Future Ones.

Part I - Financial Instability after the Global Financial Crisis: Taxonomy and Models - includes three chapters. In Chapter 1 - The Global Financial Crisis - D'Apice and Ferri recapitulate the chronology of the GFC and articulate the various concurrent factors behind it. In turn, in Chapter 2 - Minsky's financial instability hypothesis - Nikolaidi outlines how Minsky's hypothesis - something that had fallen into oblivion but was soon rejuvenated since 2008 - can help explain how the GFC came about. Moreover, Nikolaidi also explains how Minsky's analysis can be used to understand climate-induced financial instability, in the rapidly expanding area of climate-related financial risks. The first part ends with Chapter 3 - Financial accelerator framework - where Oliviero and Puopolo synthesise the main aspects of the Financial accelerator and delineate how the financial sector can amplify financial shocks through the economy.

Next, Part II - Main Channels of Transmission of the Financial Shock - consists of five chapters. In Chapter 4 - The role of the household balance sheets - André expresses the channels of transmission though which households played a major role in the GFC. Then, two chapters are devoted to encapsulate how contagion across banks contributed to the GFC. Specifically, in Chapter 5 - The European network of cross-border lending - Ricci and Stentella Lopes focus their analysis on interbank 
contagion across banks in Europe, while in Chapter 6 - International banks and the transmission of financial shocks - Cerutti and Zhou study contagion among banking networks at the global level. In turn, in Chapter 7 - The role of bank ownership types and business models - Caselli highlights the value of banking diversity, stressing how stakeholderoriented and/or traditional banks contributed less to the build-up of systemic risk before the GFC. The second part ends with Chapter $8-$ The role of market valuation in financial crises - where Bongini and Rossi discuss the role of market valuation rules at the time of the GFC and throughout its aftermath.

Part III - The Role of Public Policies - includes five additional chapters. In Chapter 9 - Reflections on the shifting consensus about monetary and fiscal policies following the GFC and the COVID-19 crises - Cukierman, building on his top-level expertise in the field, debates how the GFC and the COVID-19 crises seem to have drastically shifted the mainstream view about the role of monetary (and fiscal) policies to combat financial shocks. In Chapter 10 - Fiscal policy lessons since the Global Financial Crisis - Cohen-Setton elucidates how the role of fiscal policies has been magnified after the GFC and the euro sovereign crisis. In turn, the next two chapters expand on the role of the government when financial shocks hit the economy. Namely, in Chapter 11 - The government as lender of last resort and temporary owner - Hryckiewicz explains and provides empirical evidence that government intervention to save banks can be helpful through financial crises. Instead, in Chapter 12 - The sovereign-bank nexus - Ferri and Pesic deal with the negative link between a government and its national banking system, where the health of government finances may be strongly intertwined with the health of national banking systems, as substantiated by the euro sovereign crisis. The third part of the book ends with Chapter 13 - Financial reforms - where Garel and Petit-Romec formulate a detailed review of the main regulatory gaps evidenced by the GFC and what has been done in the following years to remedy the situation.

Finally, Part IV - Learning from Past Financial Crises to Prevent Future Ones - comprises two chapters. In Chapter 14 - Looking back: a historical perspective on European crises - Bengtsson draws on an extensive review of financial crises in Europe since the 1970s to synthesise the main recurrent factors. The book ends with Chapter 15 - Looking ahead: early warning systems - in which Davis and Karim discuss the evolution of early warning systems, a tool that may be particularly useful to forecast incoming financial crises. 


\section{INTERCONNECTIONS ACROSS THE CHAPTERS}

The 15 chapters of the book are strongly intertwined as shown by the matrix of the cross references (Table 0.1). Naturally, Chapter 1 on the GFC builds the most intense network of 20 links, expressing ten 'active' links to other chapters and receiving ten 'passive' references from other chapters. Second comes Chapter 2 - Minsky's model - with 15 links, nine active and six passive, followed by Chapter 13 - financial reforms - with 13 links (nine active and four passive) and by Chapter 9 - monetary policy - with 11 links (four active and seven passive).

\section{LOOKING AT THE FUTURE}

This book was planned before the COVID-19 pandemic hit the world. The necessary adaptation of the manual to the new situation is entrusted to the individual chapters for which the new scenario caused more important changes. However, there is something general that we can say by comparing the COVID-19 and GFC mega crises. Although the pandemic triggered an enormous financial shock - as testified by the plummeting of the main stock market indices in March 2020 (e.g., between 20 February and 20 March 2020 the Dow Jones Industrial Average lost close to onethird of its value), this is again a mega financial shock of the first type. In other words, in this case the financial shock came about because of the exogenous occurrence of the pandemic and was not originated from inside the financial sector, as happened with the GFC.

While the pandemic continued to take dramatic tolls in terms of mounting deaths and of GDP losses around the world, can we be comforted by observing that the financial shock provoked by COVID-19 was of the first type and not of the second type? Strictly speaking, yes. In reality, the repair actions via expansionary fiscal and monetary policies could work more swiftly than they had done in 2008 - and, indeed, by the end of December 2020 the Dow Jones Industrial Average had fully recovered its pre-pandemic level. However, type two financial shocks could still be around the corner, especially if we consider that more than a decade of Quantitative Easing $(\mathrm{QE})$ and close to zero interest rates may have resulted in more systemic risk build-up. The fact that unconventional monetary policies may turn into what Nickolaidi, in Chapter 2, calls "destabilising stability" seems to be receiving some support in the literature. To name a few, Lamoen et al. (2019) find that periods of QE coincide with exuberant investor behaviour in Europe, even after controlling for improving macro fundamentals, while Libich (2020) argues that monetary policy, especially 


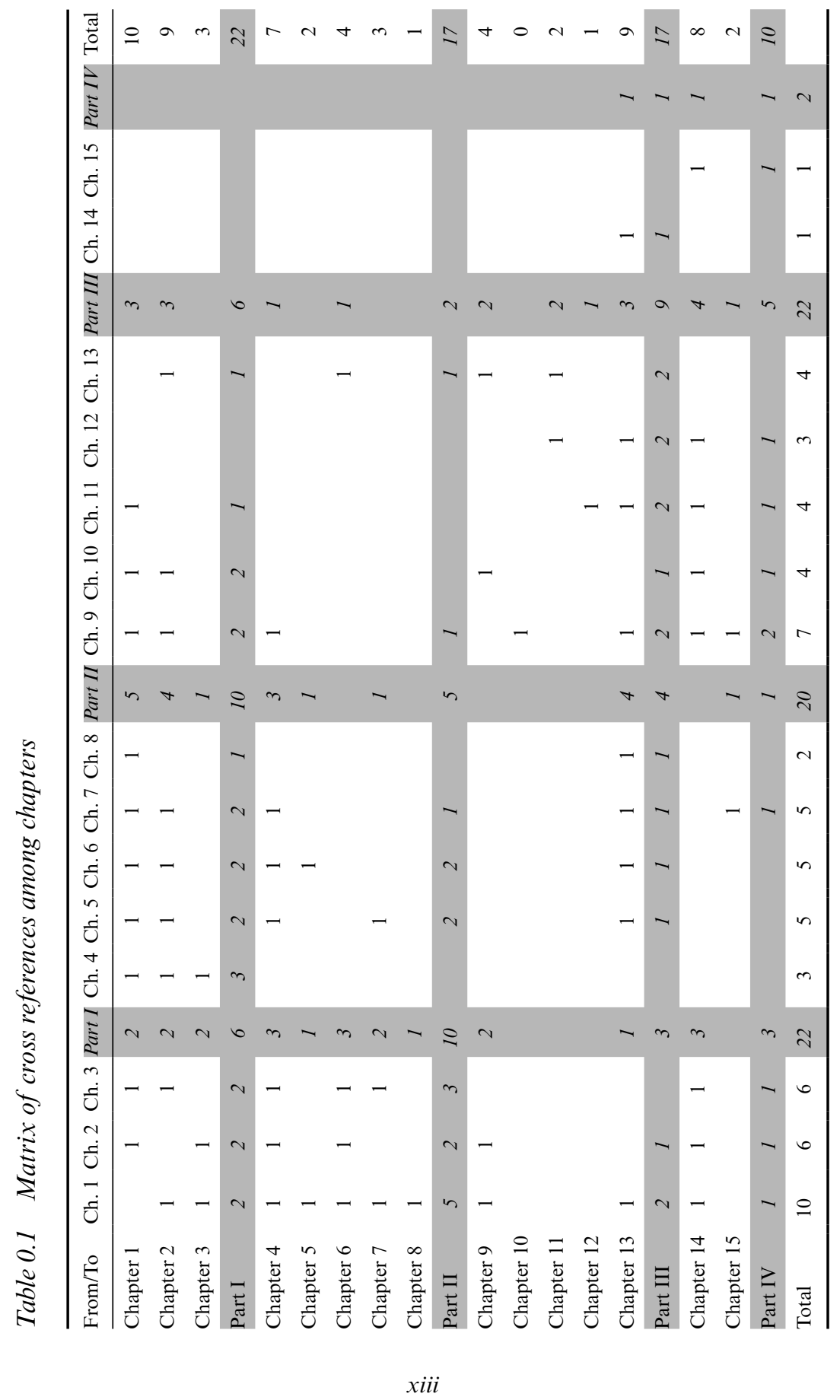


the unconventional measures (QE) implemented in the post-2008 period, has likely contributed to feed major asset bubbles with markets responding to bad news about the economy's fundamentals by stock price increases as if it was good news: in anticipation that loose monetary measures (injections of liquidity) would continue. In turn, studying the effects of interest rate cuts on investment behaviour in an experimental setting, Conrad (2019) finds that decreasing interest rates encourage risk-taking and excessive risk-taking ensues when there are no capital costs, thus leading to encourage financial bubbles and overinvestments or wrong investments under QE policies. In addition, Xu and de Haan (2018) show that the relationship between reduced credit spreads - as a result of QE - and future employment growth weakened after the Fed introduced QE. Finally, using option implied volatility indices Yang and Zhou (2017) and Yang et al. (2020) detect systemic risk spillover effects coming from US QE to the global economy.

Overall, we can reasonably hold that financial shocks will be a permanent trait in the future as well, even more so if market economies will continue in the process of expanding financialisation of the latest decades. Those readers who concur with this view will find food for thought by reading the following chapters.

\section{REFERENCES}

Conrad, C.A. (2019). The effects on investment behavior of zero interest rate policy, evidence from a roulette experiment. Applied Economics and Finance, 6(4): $18-27$.

Lamoen, R., de Vette, N., \& Hudepohl, T. (2019). Quantitative easing and exuberance in stock markets: Evidence from the Euro Area. De Nederlandsche Bank Working Paper No. 660.

Libich, J. (2020). Can money turn bad news into good news? World Economics, 21(2): 165-82.

$\mathrm{Xu}, \mathrm{Y} .$, \& de Haan, J. (2018). The time-varying relationship between credit spreads and employment growth. Applied Economics, 50(41): 4387-401.

Yang, Z., \& Zhou, Y. (2017). Quantitative easing and volatility spillovers across countries and asset classes. Management Science, 63(2): 333-54.

Yang, Z., Zhou, Y., \& Cheng, X. (2020). Systemic risk in global volatility spillover networks: Evidence from option-implied volatility indices. Journal of Futures Markets, 40(3): 392-409. 